\title{
geoquafia
} Malavsian Journal of Society and Space

\section{Kesedaran tentang masalah kemurungan dalam kalangan guru}

\author{
Manak Ek Klai, Farhana Kamarul Bahrin \\ Pusat Pengajian Sains Kemasyarakatan, Universiti Sains Malaysia, Pulau Pinang, Malaysia \\ Correspondence: Farhana Kamarul Bahrin (email: farhanabahrin@usm.my)
}

Received: 01 October 2020; Accepted: 24 November 2020; Published: 29 November 2020

\begin{abstract}
Abstrak
Masalah kemurungan merupakan salah satu masalah kesihatan mental yang berpunca daripada kurangnya pengetahuan dalam diri individu, terutamanya bagi golongan profesion perguruan. Objektif kajian adalah bertujuan untuk mengenalpasti tahap kesedaran para guru tentang masalah kemurungan. Dengan kesedaran yang ada pada para guru terhadap masalah kemurungan tersebut akan menjamin kesejahteraan hidup mereka dalam semua aspek, terutamanya dalam sistem sekolah. Seterusnya, ia akan mengekalkan produktiviti para guru dalam kehidupan seharian mereka. Kaedah analisis digunakan dalam penyelidikan kajian kualitatif ini adalah kaedah pengumpulan data secara tematik. Seramai sepuluh (10) orang responden, yang terdiri daripada guru mata pelajaran yang terlibat dengan peperiksaan awam sama ada Pentaksiran Tingkatan 3 (PT3), Sijil Pelajaran Malaysia (SPM), atau Sijil Tinggi Pelajaran Malaysia (STPM) di SMKA Al-Mashoor Perempuan, Pulau Pinang telah ditemu bual. Hasil kajian telah dianalisis secara manual dengan menggunakan kaedah teknik analisis kandungan, dan mendapati bahawa para guru rata-rata mempunyai kesedaran akan masalah kemurungan tersebut. Hal ini dikatakan demikian kerana para guru masing-masing mempunyai pengalaman secara tidak langsung terhadap masalah kemurungan, seperti mempunyai kenalan atau pelajar yang dikesan telah mengalami masalah kemurungan. Namun begitu, kefahaman para guru terhadap masalah kemurungan adalah kurang, kerana kurangnya pendedahan terhadap pendedahan masalah kemurungan kepada para guru di sekolah. Oleh hal yang demikian, penyelidik mencadangkan Akta Kerja Sosial digazetkan agar jawatan Pekerja Sosial Sekolah untuk membantu menangani masalah kesihatan mental di sekolah.
\end{abstract}

Kata Kunci: guru, kemurungan, kerja sosial di sekolah, kesejahteraan, pekerja sosial sekolah

\section{Awareness of the problem of depression among teachers}

\begin{abstract}
Depression is one of the mental health problems caused by a lack of knowledge in individuals, especially in the teaching profession. The objective of this study is to identify the level of teachers' awareness regarding the problem of depression. Awareness of this issue will ensure the well-being of teachers, resulting in teachers being able to maintain their
\end{abstract}


productivity. This qualitative study uses a thematic analysis approach. A total of 10 respondents were interviewed, consisting of subject teachers involved in the following public examinations: Pentaksiran Tingkatan 3 (PT3), Sijil Pelajaran Malaysia (SPM), and Sijil Tinggi Pelajaran Malaysia (STPM) at SMKA Al-Mashoor Perempuan, Pulau Pinang. The results of this study were analyzed manually using content analysis techniques, and found that most of the teachers are aware of the issue of depression. This is because each of the respondents had indirect experience with the issue, either through acquaintances or students who were recognised as going through depression. On the other hand, any lack of understanding among teachers about the issue of depression can be attributed to a lack of exposure to information on depression. Therefore, the researchers have proposed that the Social Work Act should be gazetted to establish the position of school social worker to help in handling mental health issues among teachers in school.

Keywords: teachers, depression, social work in school, well-being, school social worker

\section{Pengenalan}

Sistem pendidikan merupakan pemangkin kepada pembangunan negara. Hal ini dikatakan demikian kerana sistem pendidikan yang efisien akan melahirkan masyarakat yang berilmu dan berakhlak dan seterusnya dapat melahirkan modal insan yang mempunyai 'minda kelas pertama (Lee, Udin, \& Abdul Aziz, 2012). Bagi mencapai hasrat ini, para pendidik perlu menunjukkan sikap produktiviti, cekap, cergas dan berdaya usaha tinggi untuk menghasilkan mutu pendidikan yang cemerlang (Sipon, 2010). Oleh itu, pihak kerajaan telah memperkenalkan pelbagai dasar dan program untuk merealisasikan hasrat tersebut, antaranya ialah Pelan Induk Pembangunan Pendidikan 2006-2010 ataupun Pelan Pembangunan Pendidikan Malaysia 2013-2025. Oleh itu, peranan dan tanggungjawab sebagai seorang guru kini semakin kompleks dan mencabar kerana mereka perlu sentiasa memperlengkapkan diri mereka dengan pelbagai ilmu pengetahuan, pelbagai kemahiran, dan sentiasa bersedia dengan setiap perubahan yang berlaku dalam bidang pendidikan.

Guru telah diletakkan sebagai pencorak kepada pembentukan masyarakat yang berkualiti dan juga memikul tanggungjawab sebagai pendidik untuk mendidik anak bangsa. Walau bagaimanapun, tugas sebagai seorang guru bukanlah sekadar mengajar sahaja, sebaliknya mereka juga perlu menguruskan kelangsungan operasi di sekolah. Antaranya ialah tugas-tugas perkeranian, displin pelajar dan karenah rakan guru yang lain di sekolah (Lee, et al., 2012). Terdapat penyelidik yang menyatakan bahawa bidang profesion perguruan adalah satu bidang pekerjaan yang sangat stres dan masalah ini telah diambilberatkan sebagai satu masalah yang perlu dibincangkan di peringkat dunia (Kyriacou, (n.d) dalam Ahmad, 1999). Tambahan itu, bebanan guru ini akan kian meningkat mengikut perubahan piawaian yang dilakukan oleh pihak kementerian. Oleh itu, sekiranya golongan guru ini tidak dapat mengatasi cabaran dan perubahan yang berlaku terhadap bidang pendidikan akan mengakibatkan para guru ini mudah terdedah dengan masalah stres dan seterusnya akan mengakibatkan para guru kemurungan. Hal ini dikatakan demikian kerana masalah stres dan tekanan yang melampau akan memberi kesan kepada produktiviti kerja para guru dan seterusnya juga akan memberi kesan kepada fizikal serta psikologikal guru (Sipon, 2010). Kini tanggapan terhadap para guru turut berbeza, iaitu para guru akan dianggap gagal jika pelajar tidak berjaya mendapat keputusan yang cemerlang ataupun masalah disiplin yang tinggi dalam kalangan pelajar di sekolah (Ahmad, 1999). Tambahan pula, para guru kini menjadi perhatian masyarakat yang kian peka akan isu tentang pendidikan. Dalam kajian lepas telah menyatakan bahawa profesion guru merupakan bidang kerjaya yang menghadapi 
tekanan kerja yang tinggi (Ahmad, 1998). Antara penyebab utama para guru menerima tekanan kerja yang tinggi ialah sikap murid, tekanan terhadap masa, suasana di persekitaran sekolah, dan perhubungan antara staf (Boyle, Borg, Falzon, \& Baglioni, 1995).

Kesihatan mental merujuk kepada keadaan kesejahteraan individu menyedari kebolehannya, dapat mengatasi tekanan normal dalam kehidupan, dapat bekerja secara produtif dan seterusnya dapat memberikan sumbangan kepada komuniti individu tersebut (Froese-Germain \& Riel, 2012). Depresi atau kemurungan dapat dibahagikan kepada tiga (3) jenis utama iaitu minor depresi, major depresi dan manic depresi (World Federation for Mental Health, 2010). Kemurungan merupakan satu keadaan perubatan yang serius sehingga memberi kesan kepada badan, pemikiran, dan tingkah laku individu (World Federation for Mental Health, 2010). Ia memberi kesan kepada cara pemakanan dan tidur individu, cara pemikiran individu terhadap dirinya sendiri, dan juga cara individu memikirkan sesuatu perkara. Namun begitu, simptom kemurungan boleh datang dalam pelbagai bentuk, gejala, dan juga pengalaman mengikut individu yang telah disahkan kemurungan (World Federation for Mental Health, 2010). Berdasarkan kajian lepas menjelaskan bahawa masalah kemurungan ini akan menjejaskan individu di semua peringkat tanpa mengira lokasi geografi, demografi mahupun kedudukan sosial individu (Kementerian Pendidikan Malaysia, 2017). Kemurungan merupakan satu gangguan yang berlaku pada otak individu (World Federation for Mental Health, 2010). Oleh itu, penyakit ini boleh berlaku kepada sesiapa sahaja tanpa mengira jantina mahupun pekerjaan individu tersebut. Walau bagaimanapun, penyakit ini tidak mempunyai penawar untuk menyembuhkannya, tetapi terdapat pelbagai rawatan yang efektif, antara termasuklah pengunaan ubat-ubatan dan psikoterapi (World Federation for Mental Health, 2010). Individu yang mempunyai masalah kemurungan, akan lebih terdedah kepada risiko gangguan yang lain, seperti penyalahgunaan dadah, gangguan kebimbangan, penyakit jantung, strok, HIV dan AIDS, dan juga diabetes. Masalah kemurungan ini juga mempunyai risiko tinggi yang membawa kepada kes bunuh diri (World Federation for Mental Health, 2010). Oleh itu, penyelidik percaya bahawa pentingnya keperluan para guru untuk mengetahui tentang masalah kemurungan supaya masalah ini dapat dielakkan.

\section{Tinjauan literatur}

\section{Hubungkait antara guru dengan aspek kemurungan}

Guru merupakan agen penggerak kepada penentuan mutu pendidikan negara sama ada baik atau buruk. Oleh itu, penentuan kepada mutu pendidikan negara banyak bergantung kepada produktiviti yang tinggi dalam kalangan pendidik iaitu guru di sekolah (Sipon, 2010). Dalam merealisasikan sasaran ini, pihak Kementerian Pendidikan Malaysia (KPM) telah melancarkan Pelan Pembangunan Pendidikan Malaysia 2013-2025 (PPPM) yang selaras dengan Falsafah Pendidikan Kebangsaan. Antara anjakan dalam PPPM adalah usaha untuk mentransformasikan profesion perguruan. Begitu juga dengan pencapaian terhadap Wawasan 2020 yang menyasarkan sumber tenaga manusia yang berdaya saing, cekap, cergas, dan produktiviti yang tinggi (Sipon, 2010).Untuk mencapai matlamat ini, keadaan persekitaran guru haruslah kondusif dan tidak menerima cabaran dan tekanan yang terlalu tinggi di tempat kerja. Hal ini demikian kerana, cabaran dan tekanan yang terlalu tinggi akan menyebabkan guru mengalami stres yang melampau dan ia akan mengundang kepada berlakunya masalah kemurungan dalam diri guru tersebut. Tugas mendidik yang dilakukan oleh guru merupakan satu pekerjaan yang mencabar dari segi fizikal dan mental guru itu sendiri (Desouky \& Allam, 2017). Hal ini demikian kerana, guru menggunakan tenaga yang banyak dalam kehidupan sehariannya untuk mengajar di dalam kelas dan mengurus kehidupan peribadinya 
serta komitmen terhadap keluarganya. Perkara ini merupakan penyumbang yang berterusan kepada masalah tekanan dalam diri guru (Desouky \& Allam, 2017).

Isu kemurungan dan guru sememangnya mempunyai hubungkait yang sangat rapat. Hal ini demikian kerana, masalah kemurungan akan menyebabkan produktiviti guru terhadap tanggungjawab hakikinya semakin menurun. Hal ini secara tidak langsung hasrat KPM tidak dapat direalisasikan. Keadaan ini selaras dengan pandangan Zhong, You, Gan, Zhang dan Lu (2009) yang menyatakan bahawa bebanan kerja guru mempunyai hubungkait dengan keadaan kesihatan fizikal guru. Terdapat juga hasil kajian yang lepas mendapati bahawa bebanan kerja guru boleh mendatangkan masalah kemurungan (Ahola, Honkonen, \& Isometsa, 2005; Iacovides, Fountoulakis, Kaprinis, \& Kaprinis, 2003). Bebanan kerja guru yang berlebihan akan menyebabkan para guru mengalami tekanan emosi yang melampau sehingga mengganggu sesi pengajaran dan pembelajran dalam kelas. Tekanan yang melampau dalam kalangan guru ini akan menyebabkan mereka lebih empat kali ganda berisiko untuk mendapat penyakit kritikal dan seterusnya membawa kepada penyakit mental yang serius (Lee, et al., 2012). Mental yang sihat adalah penting, kerana ia akan mendorong kepada kesejahteraan hidup, kebahagiaan, serta kemampuan individu dalam menghadapi cabaran, menerima keadaan persekitaran secara terbuka dan mempunyai sifat yang positif dalam diri (Mohamad \& Ibrahim, 2018). Penyelidik bersetuju dengan kajian lepas yang menyatakan bahawa penyakit mental ini tidak berlaku dengan sendirinya sebaliknya ia disebabkan oleh faktor yang berada di sekelilingnya (Mohamad \& Ibrahim, 2018). Perkara ini jelas membuktikan bahawa bidang tugas guru sememangnya mempunyai hubungkait yang rapat dengan masalah kemurungan. Terdapat juga kajian lepas yang membuktikan bahawa bidang pendidikan ini berisiko tinggi dalam mengalami masalah tekanan (Mohamad \& Ibrahim, 2018). Bukti-bukti kajian yang lepas terhadap masalah tekanan menunjukkan hubungkait bahawa masalah ini akan memberi impak yang besar dalam bidang pendidikan serta bidang kesihatan sendiri.

\section{Kesedaran guru terhadap aspek kemurungan}

Kemurungan merupakan satu masalah kesihatan utama dan merupakan punca utama berlakunya kecacatan dan kematian di seluruh dunia (Beaudry, et al., 2019). Kajian yang lepas telah dianggarkan seramai 350 juta orang di serata dunia terjejas dengan masalah kemurungan ini (World Health Organization, 2017). Menurut WHO (2017), kemurungan merujuk kepada gangguan mental yang disebabkan oleh kesedihan, kehilangan minat atau keseronokan, perasaan bersalah atau rendah diri, gangguan sewaktu tidur, gangguan selera makan, perasaan yang letih, dan juga tumpuan yang lemah. Masalah ini sememangnya memberi kesan kepada keupayaan individu untuk berfungsi secara produktif di tempat kerja atau sekolah atau lebih besar lagi menghadapi cabaran dalam kehidupan seharian. Berdasarkan kajian lepas, mendapati bahawa kesan daripada masalah kemurungan ini ialah kegagalan di sekolah, penyalahgunaan alkohol atau penggunaan dadah, perselisihan keluarga, keganasan, dan lebih teruk lagi boleh mengakibatkan bunuh diri (Beaudry, et al., 2019). Berdasarkan kajian lepas, telah disenaraikan 20 jenis simptom yang menunjukkan seseorang itu mempunyai masalah kemurungan. Antaranya ialah sukar untuk mendapatkan kepuasan, sering menangis, rasa keletihan, sukar membuat keputusan, kurang memberi tumpuan, bimbang akan kesihatan fizikal, sentiasa berasa dirinya gagal, berasa dirinya dianiayai, berasa menyesal dan berada dalam keadaan kesedihan (Abdullah \& Rosli, 2018). Simptom ini juga dibandingkan dalam kajian yang dijalankan di New Delhi yang menyatakan bahawa seseorang itu perlu menunjukkan sekurang-kurangnya lima (5) daripada gejala ini sebagai mengesahkan bahawa mereka mempunyai masalah kemurungan, iaitu suasana yang tertekan, minat berkurangan, kehilangan berat badan yang ketara, insomnia, keletihan atau kehilangan 
tenaga, perasaan tidak berfaedah atau sering rasa bersalah, kurang tumpuan perhatian dan pemikiran yang menjurus kepada kematian (Sidana et al., 2012).

Saban hari peratusan individu yang terjejas kerana kemurungan kian meningkat. Menurut kajian yang lepas, menyatakan bahawa masalah kemurungan dalam kalangan wanita dengan lelaki adalah pada nisbah 2:1 (Ramli, Yahaya, Yahaya, \& Lazin, 2010). Manakala WHO (2017), melaporkan kemurungan sering berlaku dalam kalangan wanita $(5.1 \%)$ dan lelaki (3.6\%). Dalam profesion perguruan telah mencatatkan kekerapan berlakunya kemurungan dalam kalangan guru wanita iaitu sebanyak $43.9 \%$ berbanding dengan guru lelaki hanya 40\% (Othman \& Sivasubramaniam, 2019). Guru yang berada pada usia lingkungan 20 tahun - 49 tahun merupakan golongan yang sering terdedah kepada masalah kemurungan. Berdasarkan kepada Yen Teck Hoe dan Amirah Amaly dalam kajian Ramli, et al. (2010), golongan wanita mempunyai kekerapan yang tinggi berdepan dengan masalah kemurungan kerana berlakunya perubahan pada hormon. Dalam kajian yang lepas juga telah menunjukkan kadar peningkatan terhadap isu kemurungan dalam kalangan rakyat Malaysia sebanyak 50\% dari tahun 2011 ke tahun 2015 (Menon, 2016). Walau bagaimanapun, Tan Sri Lee Lam Tye menyatakan bahawa masalah kemurungan dijangkakan akan menjadi penyakit kesihatan mental paling utama di Malaysia menjelang tahun 2020 (Ashana, 2019).

Pengetahuan yang terhad dan tanggapan yang tidak tepat terhadap masalah kesihatan mental telah menyebabkan berlakunya layanan yang negatif terhadap pesakit mental (Akinsulore, Esimai, Mapayi, \& Aloba, 2018). Sehubungan itu, jelaslah bahawa kurangnya pengetahuan mengenai kesihatan mental dalam diri individu akan menyebabkan peningkatan peratusan terhadap masalah kesihatan mental (Safari, Kassim, Iskandar, Mohamed \& Abdullah, 2011). Perkara ini dapat dibuktikan dengan kajian yang dijalankan di Nigeria yang mendedahkan bahawa masyarakat Nigeria mempunyai maklumat yang terhad mengenai kesedaran akan masalah kemurungan (Akinsulore et al., 2018). Kemudahan dan tenaga pakar terhadap kesihatan mental di kebanyakan negara adalah sangat kurang, walaupun masalah kesihatan mental ini semakin serius. Sehubungan itu, pendapat ini turut dipersetujui oleh Jacob, Sharan, Garrido-Cumbrera, Seedat, Mari, Sreenivas dan Saxena (2007) yang mengatakan bahawa kebanyakan negara berpendapatan rendah dan sederhana hanya memperuntukkan sumber kewangan dan tenaga pakar yang sedikit terhadap isu kesihatan mental. Menurut Yeap dan Low (2009) masyarakat Malaysia mempunyai tahap pengetahuan yang rendah terhadap masalah kesihatan mental. Keadaan ini telah membuktikan bahawa kesedaran dan pengetahuan tentang kemurungan dalam kalangan guru di Malaysia turut rendah. Kekurangan kesedaran terhadap gejala ini dan punca berlakunya kemurungan telah menyebabkan individu tersebut tidak mempunyai keupayaan untuk mendapatkan bantuan golongan pakar pada masa yang tepat (Khan, 2009).

\section{Metodologi dan lokasi kajian}

Dalam kajian ini, penyelidik telah memilih untuk menggunakan reka bentuk kajian berbentuk kualitatif untuk memperoleh maklumat responden. Tujuan pemilihan pendekatan kualitatif dalam menjalankan kajian ini bertujuan sebagai pengumpulan data. Oleh itu, teknik pengumpulan data secara temu bual mendalam telah dilakukan kepada para guru yang bertugas di SMKA Al-Mashoor Perempuan. Rujukan soalan temu bual adalah menjurus kepada pengetahuan responden tentang kemurungan. Penyelidik telah melakukan pemilihan responden kajian berdasarkan kepada teknik persampelan bertujuan (purposive sampling). Hal ini demikian kerana, teknik persampelan tersebut untuk memilih responden kajian berdasarkan kepada pertimbangan penyelidik dalam memilih sampel kajian yang paling sesuai dan memenuhi syarat tujuan kajian tersebut. Walaupun saiz sampel bagi kajian ini 
tidak dapat ditetapkan pada peringkat awal kerana ia berlaku seiring dengan analisis data secara berterusan sehingga mencapai ketepuan, tetapi secara keseluruhannya penyelidik telah berjaya menemu bual seramai sepuluh (10) orang responden yang terdiri daripada golongan guru. Para responden tersebut ialah individu yang terlibat dengan pengajaran dan pembelajaran kelas yang terlibat dengan peperiksaan awam, iaitu PT3, SPM, dan STPM. Dalam kajian ini juga dapat dilihat penyelidik turut menggunakan data sekunder dalam proses penyelidikannya. Data sekunder ini merujukkan kepada sumber rujukan daripada laman web rasmi seperti kementerian, buku akademik, abstrak kajian, artikel, jurnal, dan juga laporan data statistik badan kerajaan mahupun badan bukan kerajaan (Bahrin, 2018).

Kajian dijalankan di SMKA Al-Mashoor Perempuan, Pulau Pinang dengan menyasarkan para guru yang mengajar kelas-kelas yang terlibat dengan peperiksaan awam. Pemilihan sekolah ini adalah berdasarkan kepada faktor status kecemerlangannya dalam bidang akademik dan secara tidak langsung telah menarik minat penyelidik untuk mengetahui akan komitmen para guru terhadap tekanan kerjanya.

\section{Hasil kajian}

Sebanyak 10 orang guru di SMKA Al-Mashoor Perempuan, Pulau Pinang telah dipilih secara rawak untuk ditemu ramah. Sampel terdiri daripada 9 orang guru perempuan dan seorang guru lelaki yang mengajar kelas peperiksaan awam. Hasil dapatan kajian mendapati bahawa terdapat guru yang mempunyai kesedaran akan masalah kemurungan dan tidak mempunyai kesedaran tentang masalah kemurungan. Berdasarkan dapatan kajian menunjukkan bahawa 8 orang responden mempunyai kesedaran terhadap masalah kemurungan dan dapat dibuktikan dengan penyataan definisi kemurungan oleh para responden tersebut iaitu keadaan individu yang tertekan dan seterusnya mengakibatkan berlakunya kemurungan. Jadual 1 merujuk kepada definisi yang diperolehi daripada responden menerusi sesi temu bual.

Jadual 1. Kebolehan Menyatakan Definisi oleh Responden

\begin{tabular}{ll}
\hline Responden & \multicolumn{1}{c}{ Petikan temu bual } \\
\hline Responden 1 & Kemurungan yang saya tahu ni dia berkait dengan gangguan, masalah psikologi. \\
Cikgu Mar & Ermm... Konsep kemurungan ni selalunya dia akan salahkan diri dia melampau- \\
& lampau, dia akan asingkan diri dari khalayak ramai, tak nak bergaul, dan dia rasa \\
& kelemahan diri yang ketara. \\
& ..tahun lepas tak silap sekolah pernah jemput alumni sekolah ni bagi ceramah tentang \\
& masalah stres. Penceramah tu adalah buat sesi ujian saringan dekat cikgu-cikgu. \\
Responden 2 & Ermmm... Kemurungan ah, setahu saya lah dia punca daripada tekanan, bila dia dah \\
Cikgu Haf & tertekan dia akan duduk berseorangan, jadi dia memendam apa saja masalah yang dia \\
& ada dia pendam dan tak ada tempat nak luah. Duduk sorang-sorang, waktu tidur pun \\
Responden 3 & terganggu, emosi pon terganggu. \\
Cikgu Nor & Murung ni dia macam kita stress kan diri kita. Macam kita ni tak boleh nak terima \\
& kenyataan lah. Contoh macam anak kita kena langgar meninggal dunia. Kita tak boleh \\
& nak terus-terus sedih ja. Kita kena faham konsep anak tu pinjaman dari Allah dekat \\
Responden 5 & kita. Bila dia dah pergi bererti Allah dah ambil semula apa yang dia pinjamkan dekat \\
Cikgu Che & Kemurungan apa yang saya faham dia macam kita ada masalah yang kita tak boleh \\
Responden 7 & kruskan dan buat kita rasa tertekan. Tak pun dia macam ada satu insiden yang buatkan \\
Cikgu Ain & kita trauma sampai tertekan dekat diri sendiri.
\end{tabular}


Responden 8

Cikgu Ros

Responden 9

Cikgu Zu

Responden 10

Cikgu Mah

Kemurungan ni makna dia, tekanan yang teruk. Maknanya dia sampai dah tak boleh nak berkomunikasi secara biasa dengan orang. Haaa... Maknanya dalam diri dia sikit sangat yang positif, yang banyaknya negatif. Maknanya dia pandang apa pun dia akan nampak negatif.

Mungkin dia stress lepas tu buat dia hadapi stress yang melampaulah.

Kemurungan ni apa yang kita kena tahu ialah apa punca dia yang boleh buat dia rasa murung. Dari mana datangnya kemurungan ni. Jadi kebiasaannya kemurungan ni apa yang saya boleh nampak ialah bila kita terlalu salahkan keadaan tu. Macam cikgu Manak cakap tadi, banyak kata guru ni kerja yang stress. Kenapa nak kata stress kalau kamu sendiri yang asyik salahkan keadaan tu.

Maklum balas guru terhadap definisi ini menunjukkan bahawa mereka mempunyai pengetahuan yang asas terhadap masalah kemurungan. Hal ini demikian kerana, menurut Responden 1 menyatakan bahawa pihak sekolah pernah menganjurkan Kursus Pengurusan Stres dan dalam kursus tersebut para guru telah diminta untuk mengambil Ujian Saringan Depresi. Lapan orang responden ini menunjukkan bahawa mereka memahami tentang masalah kemurungan ini berpunca daripada masalah tekanan yang mungkin dipengaruhi daripada pelbagai faktor, sama ada daripada faktor tugasan, ibu bapa, pelajar, mahupun faktor disekelilingnya. Berdasarkan kepada data yang diperolehi daripada temu bual, telah disenaraikan beberapa simptom jika seseorang itu mempunyai masalah kemurungan (Jadual 2). Dapatan kajian ini dapat memperkukuhkan lagi kesedaran responden tentang masalah kemurungan.

Jadual 2. Simptom-simptom Kemurungan

\begin{tabular}{ll}
\hline \multicolumn{1}{c}{ Responden } & \multicolumn{1}{c}{ Petikan temu bual } \\
\hline Responden 8 & Kemurungan ni selalunya orang tu akan duduk sorang diri, dia memang tak boleh \\
Cikgu Ros & buat apa sebab dia macam takut nak berjumpa orang. Aktiviti harian dia dah tak \\
& macam biasa, lepas tu kebanyakannya ermm... mereka akan lukakan diri sendiri \\
& takpun rasa nak bunuh diri. \\
Responden 9 & Saya rasa ... mungkin dia rasa tak seronok kot, dia tak banyak cakap ermm ... tak \\
Cikgu Zu & suka terlibat dengan aktiviti- aktiviti yang ramai-ramai ni. \\
\hline
\end{tabular}

Berdasarkan hasil temu bual, mendapati bahawa seramai 10 orang guru yang mempunyai pengalaman secara langsung terhadap masalah kemurungan (Jadual 3). Hal ini demikian kerana, kesemua responden mempunyai kenalan yang menghadapi masalah kemurungan, sama ada melibatkan ahli keluarga, rakan sekerja, mahupun pelajar. Dapatan kajian ini membuktikan bahawa, para responden mempunyai pengetahuan tentang kemurungan secara langsung.

Jadual 3. Pengalaman Responden terhadap Masalah Kemurungan

\begin{tabular}{ll}
\hline \multicolumn{1}{c}{ Responden } & \multicolumn{1}{c}{ Adakah anda mempunyai kenalan yang mengalami masalah kemurungan } \\
\hline Responden 1 & $\begin{array}{l}\text { Ex-pelajar sekolah ni. Sebab perwatakan dia memang menunjukkan dia murung. Tapi } \\
\text { baru ni saya jumpa dia, dia dah elok dah, normal balik. Mungkin ayah dia bawa pi berubat } \\
\text { kot. Ada juga pelajar sini yang murung tapi sekarang dia dah ada kat Matrik lah. Dulu dia } \\
\text { ada minta dekat sekolah untuk tak nak 'join' rakan-rakan lain dalam apa-apa bengkel pon. }\end{array}$ \\
& $\begin{array}{l}\text { Memang dia yang pergi minta. } \\
\text { Dalam kenalan guru mungkin ada tapi tak terlalu serius. }\end{array}$ \\
$\begin{array}{l}\text { Responden 2 } \\
\text { Cikgu Haf }\end{array}$ & $\begin{array}{l}\text { Ada. Ustazah ada seorang kawan baik. Anak dia kawan dengan anak Ustazah. Kemudian } \\
\text { Responden 3 } \\
\text { Cikgu Nor }\end{array}$ \\
kemak dia 'accident' meninggal dunia. So dia lama juga, lebih kurang 4 bulan juga dia \\
\end{tabular}


Responden 4

Cikgu Maz

Responden 5

Cikgu Che

Responden 6

Cikgu Ai

Responden 7

Cikgu Ain

Responden 8

Cikgu Ros

Responden 9

Cikgu Zu

Responden 10

Cikgu Mah
Cikgu ada ex-student Cikgu yang memang kemurungan. Ramai.

Ada. Anak murid sekolah ni ada yang ada kemurungan. Teruk juga lah

Saya rasa kebanyakan mereka ni alami tekanan ja belum sampai tahap kemurungan lagi.

Ada. Anak buah saya, umur 28tahun baru kot. Baru jadi cikgu 23 tahun. Dia dah jadi depress. Dia sebab duduk jauh dari suami lepas tu dia mengandung pula.

Ada. Kawan anak saya. Masa tu anak saya belajar di Brunei, kawan dia duduk sekali dekat rumah sewa.

Ermm... Takda lah sangat sampai murung ermm.. Tak tau Haha... stres tu mungkin lah.

Ada. Anak Ustazah sendiri yang mengalami kemurungan, dan Ustazah ada hantar dia ke Psikiatri untuk dapatkan rawatan.

Di samping itu, berdasarkan kepada hasil kajian juga menunjukkan 2 orang responden daripada 10 orang responden, tidak memahami akan masalah kemurungan (Jadual 4). Hal ini demikian kerana, responden gagal untuk menjelaskan definisi berkenaan dengan masalah kemurungan.

Jadual 4. Kegagalan Menjelaskan Definisi Kemurungan

Responden $\quad$ Petikan temu bual

Responden $6 \quad$ Kemurungan ni dalam... dalam... konteks guru, kemurungan ni berlaku bila mana kita Cikgu Ai tengok dalam ahhh... kerja buat guru, kita bagilah tugasan apa pun, dari segi keberhasilan kerja dia tu. Kalau dia memberi responds yang baik, adakah itu murung. Tak kan.kalau kerja buat dia $100 \%$ okay, dia dalam kategori jaga prestasi. Mungkin murung tu sebab personaliti dia tidak suka bergaul dengan orang yang buang masa kerja dia, lebih baik dia fokus kepada orang yang boleh bantu dia. Sebab kategori manusia ni ada tiga jenis, ada... autokratik, ada... demokrasi, lepas tu lazzis-faire. Ketiga-tiga ni mempengaruhi juga dalam kerja buat seorang guru. Jadi bila kita amalkan budaya kita duduk dalam kategori ni, saya rasa benda-benda yang masalah kemurungan ni kita boleh atasi. Cuma kita kena sentiasa ingat pada diri kita lah.

Responden $4 \quad$ Macam mana eh... Cikgu rasa sebab dia suka bandingkan diri sendiri dengan orang lain. Cikgu Maz Apa yang orang ada, kita pun nak juga. Kalau tak dapat tu lah 'depress'. Ha itulah, kemurungan ni berlaku bila kita tak dapat nak terima.

\section{Perbincangan}

Dapatan kajian telah menunjukkan bahawa majoriti guru di SMKA Al-Mashoor Perempuan, Pulau Pinang mempunyai kesedaran tentang masalah kemurungan. Hal ini demikian kerana, pengetahuan tentang kemurungan adalah selaras dengan pandangan penyelidik yang lepas. Hasil kajian dilihat kosisten dengan kajian Bullare@Bahari et al. (2015) yang menyatakan bahawa keadaan tertekan ini akan menyebabkan kemurungan sekiranya tidak ditangani dengan baik. Dapatan kajian ini juga selari dengan dapatan penyelidikan Hassan (2018) yang menyatakan bahawa individu yang mempunyai tekanan semasa berada di tempat kerja akan mempunyai kecenderungan yang tinggi untuk menghadapi masalah kemurungan berbanding dengan individu yang tidak mempunyai masalah tekanan (Hassan, 2018). Antara tekanan yang diterima oleh guru ialah tekanan daripada bebanan kerja, tekanan daripada ibu bapa, dan tekanan daripada pihak atasan. Perkara ini diperkukuhkan lagi dengan pendapat penyelidik yang lepas dengan membuktikan bahawa tekanan guru adalah berpunca daripada tekanan oleh ibu bapa, masyarakat, pihak kerajaan, pertubuhan, dan pihak atasan serta tekanan daripada masalah peribadi guru (Ali, 2011). Selain itu, pendapat ini juga persetujui oleh kajian Hong dan Ismail (2015) yang mengatakan bahawa tekanan guru bermula apabila 
terpaksa melayan karenah daripada pihak ibu bapa, masyarakat, pihak atasan, kerajaan dan dalam masa yang sama mempunyai masalah peribadi.

Masalah kemurungan dikatakan telah memberi kesan kepada masalah kesihatan yang lain sama ada masalah penyakit kronik mahupun kadar bunuh diri yang kian meningkat dalam sesebuah negara. Keadaan tersebut akan memberi impak kepada produktiviti para guru dalam melaksanakan sesuatu tugasan. Kemurungan ini merupakan satu keadaan perubatan yang serius sehingga memberi kesan kepada badan, pemikiran, dan tingkah laku individu. Ia memberi kesan kepada cara pemakanan dan tidur individu, cara pemikiran individu terhadap dirinya sendiri, dan juga cara individu memikirkan sesuatu perkara. Shyangwa, Singh dan Khandelwal (2003), menyatakan bahawa pengetahuan berkaitan dengan kemurungan adalah sangat penting, namun begitu sikap masyarakat terhadap kesihatan mental ini berada pada tahap yang rendah. Secara tidak langsung, perkara ini telah menyebabkan masyarakat kini jahil akan masalah kemurungan (Safari et al., 2011). Hal ini demikian kerana, dengan pengetahuan yang luas tentang isu kesihatan mental ini dapat mengelakkan individu daripada penyakit kemurungan serta masalah mental yang lain. Perkara ini bersesuaian dengan hasrat yang diletakkan oleh WHO yang menganggarkan bahawa satu daripada lima orang penduduk dunia akan menghidapi penyakit mental dalam kehidupan mereka, namun begitu keadaan ini dapat diubati sekiranya individu mempunyai kesedaran yang tinggi bersertakan dengan sokongan disekelilingnya bagi menghalang penyakit tersebut merebak (Safari, et al., 2011). Secara tidak langsung, perkara ini akan mengekalkan kesejahteraan hidup individu. Oleh itu, dengan adanya kesedaran terhadap masalah kemurungan akan menyebabkan para guru tahu mengurus tahap tekanan dalam diri mereka, seterusnya dapat menghindari daripada terlibat dengan kemurungan. Selain itu, dengan kesedaran yang tinggi ini juga dapat membantu para guru untuk mengenal pasti simptom berlakunya kemurungan terhadap individu di sekelilingnya. Hal ini demikian kerana, dengan pengesanan awal ini dapat membantu individu-individu yang terdedah dengan masalah kemurungan boleh mendapatkan rawatan dengan lebih awal. Hal ini demikian kerana, sekiranya tekanan ini tidak diatasi dengan baik dan berpanjangan ia akan meninggalkan kesan buruk kepada kesihatan individu (Zafir, 2010). Selain itu, masalah tekanan yang tidak diurus dengan baik juga akan memberi kesan kepada hal rumah tangga serta mengganggu hubungan sosial individu dalam kehidupan seharian (Zafir, 2010). Oleh itu, kesedaran terhadap masalah kemurungan selain dapat menghindari daripada terjebak dengan masalah kesihatan mental, ia juga dapat memastikan kesejahteraan hidup para guru terjamin seperti sedia kala. Seterusnya, ia juga dapat membantu meningkatkan kefungsian sosial pada sistem di sekolah dan memastikan kualiti prestasi guru di sekolah tidak terjejas dengan masalah kemurungan yang dihadapi oleh guru-guru tersebut.

Masalah kemurungan yang berlaku ini, mungkin mengambil masa untuk menghidaptinya dan mempunyai simptom yang berbeza kepada setiap individu. Namun begitu, tiada ubat untuk mengatasi masalah kemurungan, sebaliknya ia boleh dirawat (World Federation for Mental Health, 2010). Sekiranya masalah kemurungan ini berlaku dalam tempoh jangka masa panjang, jelas menunjukkan bahawa individu tersebut memerlukan pelbagai model intervensi untuk mengatasinya (Huberty, 2010). Antara intervensi yang boleh digunakan bagi mengurangkan masalah kemurungan tersebut ialah terapi keluarga, kerja individu ataupun kumpulan, dan intervensi yang menggunakan ubat-ubatan. Psikoterapi atau juga dikenali sebagai terapi perbualan ataupun kaunseling sememangnya dapat membantu individu yang mengalami kemurungan. Antara terapi yang dibuktikan berkesan dalam membantu mengatasi masalah kemurungan dalam kajian yang lepas ialah Cognitive Behavioral Therapy dan terapi interpersonal (World Federation for Mental Health, 2010). Walau bagaimanapun, sekiranya individu mengalami masalah kemurungan yang melampau, mereka memerlukan bantuan daripada pakar dan memerlukan sokongan serta tumpuan yang lebih, tetapi bukan layanan yang negatif seperti dikritik, didenda, ataupun sikap indifference 
(Huberty, 2010). Berdasarkan dapatan kajian ini, penyelidik mencadangkan bahawa keperluan pekerja sosial sekolah adalah amat diperlukan. Hal ini demikian kerana, dengan kewujudan pekerja sosial yang bertugas di sekolah sememangnya dapat memberi pendedahan yang lebih awal kepada para guru berkaitan dengan isu kesihatan mental. Secara tidak langsung ia juga akan membantu dalam mencapai Anjakan ke-4 dalam Pelan Pembangunan Pendidikan Malaysia (PPPM) yang diusahakan oleh KPM untuk mentransformasi profesion perguruan menjadi profesion pilihan. Dengan wujudnya Pekerja Sosial Sekolah bukan sahaja dapat mengembalikan kefungsian guru dan pelajar malah pekerja sosial juga bertindak sebagai broker dalam menyalurkan dan menghubungkan keluarga pelajar dengan sumbersumber penyelesaian masalah wujud (Asalal et al., 2012). Seterusnya, ia juga akan mengekalkan dan mengembalikan kesejahteraan hidup para guru.

\section{Kesimpulan}

Perubahan yang kerap dan beban kerja yang banyak dalam bidang pendidikan ini sedikit sebanyak telah menyebabkan para guru terkesan untuk menghadapi masalah tekanan yang berkemungkinan besar akan membawa kepada masalah kemurungan. Selain daripada mempersiapkan diri dengan sebarang perubahan yang bakal dilakukan oleh pihak kementerian, para guru juga perlu peka akan kesan yang bakal mereka hadapi sekiranya gagal dalam menempuh cabaran ini. Oleh itu, secara keseluruhannya, kajian ini telah menjawab kesemua persoalan kajian dan mencapai objektif kajian yang telah ditetapkan oleh penyelidik pada awal tujuan kajian tersebut dijalankan. Responden kajian ini pada dasarnya mempunyai pengetahuan tentang masalah kemurungan tetapi tidak secara mendalam. Hal ini demikian kerana, kurangnya pendedahan tentang masalah kesihatan mental dalam kalangan profesional perguruan. Oleh itu, penyelidik percaya dengan wujudnya pekerja sosial sekolah akan membantu dalam memberi pendedahan awal tentang masalah kemurungan kepada semua pihak di sekolah, terutamanya golongan guru.

\section{Rujukan}

Abdullah, N. A. S., \& Rosli, N. A. (2018). Kemurungan dalam kalangan mualaf di pusat pengajian PERKIM Wilayah Persekutuan. Malaysian Online Journal of Counseling, 5(1), 52-63.

Ahmad, M. (1998). Tekanan kerja di kalangan guru sekolah menengah: 115 Satu kajian di daerah Kulim Bandar Baharu, Kedah Darul Aman. Disertasi Sarjana Sains. Universiti Malaysia Sarawak: Bintulu. 119 pp.

Ahola, K., Honkonen, T., \& Isometsa, E. (2005). The relationship between job-related burnout and depressive disorders - results from the Finnish Health 2000 Study. Journal of Affective Disorders, 88(2005), 55-62.

Ali, R. M. D. R. (2011). Faktor-faktor yang mendorong tekanan kerja (stres) di kalangan guru-guru sekolah menengah di daerah Pasir Puteh. Disertasi Sarjana Pendidikan. Open University Malaysia. 109 pp.

Akinsulore, A., Esimai, O. A., Mapayi, B. M., \& Aloba, O. O. (2018). Public awareness and attitude towards depression: a community based study among an adult population in Ile-Ife south western Nigeria. Community Mental Health Journal, 54(6), 866-874.

Ashana, N. R. N. (2019). Depresi Pembunuh Senyap Remaja Malaysia. Sinar Online. Diambil daripada https://www.sinarharian.com.my/article/29093/Analisis-Sinar/ Depresi-pembunuh-senyap-remaja-Malaysia 
Bahrin, F. K. (2018). Pembentukan dan keberkesanan modul dalam perubahan pengetahuan, persepsi dan tingkah laku pelajar sekolah menengah terhadap HIV/AIDS di Pulau Pinang. Tesis Doktor Falsafah. Universiti Sains Malaysia: Penang. 232 pp.

Beaudry, M. B., Swartz, K., Miller, L., Schweizer, B., Glazer, K., \& Wilcox, H. (2019). Effectiveness of the adolescent depression awareness program (ADAP) on depression literacy and mental health treatment. Journal of School Health, (3), 165-172.

Boyle, G. J., Borg, M. G., Falzon, J. M., \& Baglioni, A. J. (1995). A structural model of the dimensions of teacher stress. British Journal of Educational Psychology, 65(1), 4967.

Bullare@Bahari, F., Ismail, R., Madlan@Endalan, L., \& Lajuma, S. (2015). Strategi daya tindak remaja sekolah dan hubungannya dengan kemurungan. Jurnal Psikologi Malaysia, 1(29), 21-38.

Desouky, D., \& Allam, H. (2017). Occupational stress, anxiety and depression among Egyptian teachers. Journal of Epidemiology and Global Health, 7(3), 191-198.

Froese-Germain, B., \& Riel, R. (2012). Understandint teachers' perspectives on student mental health: findings from a national survey. Canada: Canadian Teachers' Federation.

Gani, F. A. (2019). Gejala kemurungan: Kesedihan biasa atau penyakit? Kolumnis Awani Malaysia. Diambil daripada http://www.astroawani.com/berita-malaysia/gejalakemurungan-kesedihan-biasa-atau- penyakit-196621

Hassan, N. N. N. (2018). Kesan modul terapi realiti (MTR) terhadap penghargaan kendiri dan kemurungan mangsa buli. PhD Tesis. Universiti Sains Malaysia: Penang. 246 pp.

Hong, O. C., \& Ismail, A. (2015). Sokongan pihak pengurusan sekolah terhadap tekanan kerja guru di sekolah kebangsaan dan sekolah jenis kebangsaan cina. Jurnal Kepimpinan Pendidikan, 2(2). 42-57.

Jacob K., Sharan P., Mirza I., Garrido-Cumbrera, Seedat S., Mari J., Saxena S. (2007). Mental health systems in countries: where are we now? The Lancet, 370, 1061-1077.

Jamaliyah Ahmad. (1999). Risiko kesihatan akibat stres di kalangan guru-guru sekolah menengah sekitar Wilayah Persekutuan Kuala Lumpur. Disertasi Sarjana Sains. Universiti Putra Malaysia: Selangor. 36 pp.

Jari, I. (2012). Pengaruh perilaku kepimpinan pengetua ke atas tekanan kerja guru sekolah menengah di Melaka. PhD Tesis. Universiti Malaya: Kuala Lumpur. 403 pp.

Kementerian Pendidikan Malaysia. (2017). Depression, anxiety and stress among firefighters at one of balai bomba in Negeri Sembilan - a case study. Jurnal Psikologi Dan Kaunseling, 8, 194-211.

Khan, T. M. (2009). Evaluation of public knowledge and clinical management of depression in the state of Penang, Malaysia. Disertasi Sarjana Sains. Universiti Sains Malaysia: Penang. $135 \mathrm{pp}$.

Lee, G. M., Udin, A., \& Abdul Aziz, M. H. (2012). Persepsi guru terhadap kesihatan mental di sekolah menengah di Perak. Journal of Educational Psychology \& Counseling Mental Health, 7, 1-10.

Manthei, R., Gilmore, A., Tuck, B., \& Adair, V. (1996). Teacher stress in intermediate schools. Educational Research, 38(1), 3-19.

Menon, J. (2016). Depression on the rise as Malaysians burn out from stress, expert warns. TheMalayMailOnline. Diambil daripada http://www.themalaymailonline.com/ malaysia/article/depression?on?the?rise?as?malaysians?burn?out?from?stress? expert? warns

Mohamad, M. S., \& Ibrahim, R. (2018). Perbezaan gender tekanan psikologikal dan kesihatan mental dalam kalangan pelajar prasiswazah. Jurnal Personalia Pelajar, 21(1), 55-66. 
Othman, Z., \& Sivasubramaniam, V. (2019). Depression, anxiety, and stress among secondary school teachers in Klang, Malaysia. International Medical Journal, 26(2), 71-74.

Ramli, J., Yahaya, A., Yahaya, N., \& Lazin, S. Z. M. (2010). Kemurungan dalam kalangan penghuni rumah anak yatim di daerah Kota Bharu, Kelantan. Journal of Science \& Mathematics Education. Diambil daripada http://eprints.utm.my/id/eprint/10127/

Safari, I. N. M., Kassim, N., Iskandar, N. F., Mohamed, M. H., \& Abdullah, M. Y. (2011). Tahap pengetahuan mengenai kesihatan mental dalam kalangan pelajar institut pengajian tinggi awam (IPTA): kajian kes di UKM, Bangi. Jurnal Personalia Pelajar, 14, 37-44.

Shyangwa P., Singh S., \& Khandelwal S K. (2003). Knowledge and attitude about mental illness among nursing staff. Journal of Nepal Medical Association, 42, 27-31

Sidana, S., Kishore, J., Ghosh, V., Gulati, D., Jiloha, R., \& Anand, T. (2012). Prevalence of depression in students of a medical college in New Delhi: A cross-sectional study. Australasian Medical Journal, 5(5), 247-250.

Sipon, S. (2010). Stres kerja guru: punca, kesan dan strategi daya tindak. Dalam Prosiding Seminar Profesion Perguruan.

TheSunDaily. (2016). Stop stigma against depression. The Sun Daily. Diambil daripada https://www.thesundaily.my/archive/1736827-XSARCH356535

World Federation for Mental Health. (2010). Depression: What you know can help you International perspectives on depression for people living with depression and their families. USA: World Federation for Mental Health.

World Health Organization. (2017). Depression and Other Common Mental Disorders: Global Health Estimates. Geneva: World Health Organization.

Yeap, R., \& Low. W. Y. (2009). Mental health knowledge, attitude and help-seeking tendency: a Malaysian context. Singapore Medical Journal, 50(12), 1169-1176.

Zafir Mohd Makhbul. (2010). Benarkah stres mengancam kualiti kehidupan?. Dalam Prosiding Bengkel Pemantauan dan Pembentangan Output Penyelidikan.

Zakaria U. K. (2014). Faktor-faktor yang mempengaruhi tekanan kerja dalam kalangan guru sekolah menengah daerah Hulu Terengganu, Terengganu Darul Iman. Disertasi Sarjana. Universiti Utara Malaysia: Kedah. 141 pp.

Zhong, J., You, J., Gan, Y., Zhang, Y., \& Lu, C. (2009). Job stress, burnout, depression symptoms, and physical health among Chinese university teachers. Psychological Reports, 105(3), 1-7. 